\title{
Radio-Iodine Conjugated (Linked) to Chemotherapy or Targeted Medication: Any Place in the Management of Differentiated Thyroid Cancers
}

\author{
Omar Ramadan* \\ Department of ENT, Paterson NJ, USA
}

Submission: March 31, 2017; Published: April 06, 2017

*Corresponding author: Omar Ramadan, Independent researcher, ENT registrar, Paterson NJ, USA

\section{Letter to Editor}

The thyroid gland is composed primary of follicular cells, C cells, and the necessary supporting stroma. The follicular cells have a property of taking up iodine in order to synthesize it into thyroid hormone and finally releasing the hormone in the blood in response to TSH. These follicular cells may develop into differentiated thyroid cancer and are the chief focus of this article. Most thyroid malignancies are differentiated thyroid cancers of follicular cell origin. Differentiated thyroid cancers can be divided into papillary, follicular and hürthle cell types. Differentiated thyroid cancers have typically iodine affinity and can be managed with radioiodine. In most patients, radioiodine treatment is conducted for ablation of residual thyroid tumor, and in these patients we should use the minimum possible dose, also an Adjuvant therapy can be done to decrease the risk of recurrence. In other hand,patients with advanced metastatic disease may need the maximum-tolerated dose.Recent researches have focused on better patient selection and reduced radioiodine doses for remnant ablation [1].

There are many outgoing targeted therapeutic approaches in patients who are appeared to have iodine-refractory disease; some of them used targeted therapeutics alone or in combination with radioiodine. Sorafenib and lenvatinib, small-molecule multikinase inhibitors, were all approved for the treatment of progressive, symptomatic, radioactive iodine refractory, advanced differentiated thyroid cancer [2]. Also there are numerous articles taking about (Antibody Drug Conjugates) as antibodies carrying cytotoxic drugs. [3-6]. Riva et al. [6] try to treat metastatic colorectal cancer by means of specific monoclonal antibodies conjugated with iodine-131. Two out of 15 evaluable patients achieved complete remission, 2 partial remission with a response rate of $26.6 \%$ and the disease stayed stable in 3 patients.
But what if we use iodine (radioactive or normal) as a carrier or a guide for the cytotoxic drugs in thyroid cancers. The iodine will carry the chemotherapeutic or targeted medication to accumulate mainly in the malignant thyroid tissue, then radioiodine and the chemotherapeutic or targeted medication will kill specifically the malignant thyroid tumor, by this way we are going to synergetic the effect of radioiodine and we are going to decrease the dosage of chemotherapeutic or targeted medication so we are decreasing the toxicity and side effects [7]. We can also use this method in multiple kinds of tumors, just be selection the appropriate carrier that accumulate naturally in the malignant tissue and linked it with chemotherapeutics or targeted therapy. This is a novel therapy that needs multiple researches by pharmacologists to find that linked-medication, and multiple clinical trials by physicians to find if this medication may help in the management of thyroid cancers especially radioresistance cases.

\section{References}

1. Pryma DA, Mandel SJ (2014) Radioiodine therapy for thyroid cancer in the era of risk stratification and alternative targeted therapies. J Nucl Med 55(9): 1485-1491.

2. Carneiro RM, Carneiro BA, Agulnik M, Kopp PA, Giles FJ (2015) Targeted therapies in advanced differentiated thyroid cancer. Cancer Treat Rev 41(8): 690-698.

3. Pascual MH, Verdier P, Malette P, Mnich J, Ozoux ML (2013) Validation of an immunoassay to selectively quantify the naked antibody of a new Antibody Drug Conjugate-SAR566658-for pharmacokinetic interpretation improvement. J Immunol Methods 396(1-2): 140-146.

4. de Goeij BE, Peipp M, de Haij S, van den Brink EN, Kellner C, et al. (2014) HER2 monoclonal antibodies that do not interfere with receptor heterodimerization-mediated signaling induce effective internalization and represent valuable components for rational antibody-drug conjugate design. MAbs 6(2): 392-402.

5. Rodriguez-Aller M, Guillarme D, Beck A, Fekete S (2016) Practical method development for the separation of monoclonal antibodies and antibody-drug-conjugate species in hydrophobic interaction 
chromatography, part 1: optimization of the mobile phase. J Pharm Biomed Anal 118: 393-403.

6. Yang Y, Guo Q Chen X, Zhang J, Guo H, et al. (2016) Preclinical studies of a Pro-antibody-drug conjugate designed to selectively target EGFRoverexpressing tumors with improved therapeutic efficacy. MAbs 8(2) 405-413.
7. Riva P, Marangolo M, Tison V, Armaroli L, Moscatelli G, et al. (1991) Treatment of metastatic colorectalcancer by means of specific monoclonal antibodies conjugated with iodine-131: a phase II study. Int J Rad Appl Instrum B 18(1): 109-119.

\section{Your next submission with Juniper Publishers} will reach you the below assets

- Quality Editorial service

- Swift Peer Review

- Reprints availability

- E-prints Service

- Manuscript Podcast for convenient understanding

- Global attainment for your research

- Manuscript accessibility in different formats

( Pdf, E-pub, Full Text, Audio)

- Unceasing customer service

Track the below URL for one-step submission https://juniperpublishers.com/online-submission.php 